\title{
Pulmonary resection for metastases from hepatocellular carcinoma: Factors influencing prognosis
}

Takahito Nakagawa, MD, Toshiya Kamiyama, MD, Kazuaki Nakanishi, MD, Hideki Yokoo, MD, Hirofumi Kamachi, MD, Michiaki Matsushita, MD, Satoru Todo, MD

Objective: Although the lung is the most common site of extrahepatic spread from hepatocellular carcinoma, outcomes after pulmonary resection and prognostic factors have not been well described. We analyzed a single-center experience with 25 patients undergoing pulmonary resection of metastases from hepatocellular carcinoma to examine the clinical factors and outcomes.

Methods: Patients were candidates for resection if they had controlled intrahepatic disease with no evidence of extrathoracic lesions and if all gross tumors could be removed with preservation of respiratory function. Twenty-five patients with hepatocellular carcinoma who underwent curative hepatectomy were suitable for the pulmonary resection criteria between 1990 and 2005. Clinical features and outcomes were analyzed.

Results: The mean actuarial 1-, 3-, and 5-year survivals after pulmonary resection were $80 \%, 61 \%$, and $36 \%$, respectively. Tumor number (solitary or multiple) and location (unilateral or bilateral lung) did not significantly affect cancer-specific survival. Mean 5-year survival was $25 \%$ for patients with disease-free interval of 1 to 11 months and $62 \%$ for those with disease-free interval of 12 months or more. Mean survival was 15.9 months for patients with alpha-fetoprotein of $500 \mathrm{ng} / \mathrm{mL}$ or more, and 39.2 months for those with alpha-fetoprotein less than $500 \mathrm{ng} / \mathrm{mL}$. Five-year survival was $21 \%$ for patients with short disease-free interval or high alpha-fetoprotein level and $74 \%$ for those with long disease-free interval and low alpha-fetoprotein level $(P=.015)$.

Conclusion: Pulmonary resection for metastases from hepatocellular carcinoma may prolong survival in selected patients. Disease-free interval greater than 12 months and alpha-fetoprotein less than $500 \mathrm{ng} / \mathrm{mL}$ are important prognostic factors.

From the Department of General Surgery, Hokkaido University, Graduate School of Medicine, Sapporo, Japan.

Received for publication Dec 15, 2005; accepted for publication Feb 10, 2006

Address for reprints: Takahito Nakagawa, MD, Department of General Surgery, Hokkaido University, Graduate School of Medicine, N15W7 Kita-ku, Sapporo, Japan (Email: nakanbo@med.hokudai.ac.jp).

J Thorac Cardiovasc Surg 2006;131:1248-54 $0022-5223 / \$ 32.00$

Copyright $(\odot) 2006$ by The American Association for Thoracic Surgery

doi:10.1016/j.jtcvs.2006.02.009
$\mathrm{H}$ epatocellular carcinoma (HCC) is a highly fatal cancer. It is common in Japan, ${ }^{1}$ and its incidence in the United States, ${ }^{2}$ Europe,${ }^{3}$ and the rest of the world is increasing. Recent progress in the diagnosis and treatment of HCC has improved patient outcomes. Advances in surgical techniques and perioperative management have reduced the operative morbidity and mortality of patients with HCC. However, the long-term outcome of patients with HCC remains poor because of a high incidence of recurrence after hepatic resection. The most frequent organ in which HCC recurs is the liver; the lung is the most common site of extrahepatic spread. $^{4}$

Although several case reports ${ }^{5-7}$ and small studies ${ }^{8-10}$ have been published in the English-language literature about surgical resection of pulmonary metastases from HCC, the indications for these procedures and the prognostic factors have not yet been standardized. We reviewed our experience with surgical treatment of pulmonary metastases from HCC to analyze the clinical factors and outcome. 

Abbreviations and Acronyms
AFP = alpha-fetoprotein
CT = computed tomography
DFI $=$ disease-free interval
HCC = hepatocellular carcinoma
$\mathrm{TACE}=$ transcatheter arterial chemoembolization

\section{Methods}

Between January 1987 and December 2003, 544 patients with HCC underwent curative partial hepatectomy in the Department of General Surgery, Hokkaido University Hospital. Twelve patients died in the hospital. The remaining 532 were followed after surgery at the outpatient clinic at intervals of 3 months with serum alpha-fetoprotein (AFP) measurements and abdominal computed tomography (CT) scans. Pulmonary recurrence was also checked by chest radiograph, and chest CT was performed when AFP was increased or recurrence was suspected.

Selection criteria for pulmonary resection were as follows: no evidence of uncontrollable intrahepatic disease, no evidence of metastatic disease at another site, and CT demonstrating that complete resection could be performed regardless of the number of lesions. Tumors in the bilateral thorax were not considered to be a contraindication. In patients in whom additional lung metastases developed after resection, further resection was performed if there was no other visceral recurrence. Patients with uncontrolled liver disease or unresectable multiple lung metastases were offered chemotherapy.

Principally, wedge resection was the procedure of choice, and lymph node dissection was not undertaken.

Data on patients' clinical characteristics, serum AFP level immediately before pulmonary resection, operative findings, and operative outcomes were obtained from the Hepatobiliary and Pancreatic Service Database of the Department of General Surgery.

The disease-free interval (DFI) comprised the period between the last curative treatment for intrahepatic disease and the detection of pulmonary deposits.

\section{Statistics}

The chi-square test was used to compare categoric variables between the 2 groups. The unpaired $t$ test was used to compare continuous variables. Survival was estimated by the Kaplan-Meier method, and differences between survival curves were tested by the log-rank test. Overall survival after pulmonary resection was calculated using data on all resected patients. For analysis of clinical factors related to the pulmonary tumor, 1 patient who died in the early postoperative period was excluded. Statistical analysis was performed using StatView for Windows (Version 5.0, SAS Institute Inc, Cary, NC).

\section{Results}

Twenty-five patients were suitable in the criteria of pulmonary resection, and curative pulmonary resection was per- formed in all of them between 1990 and 2005. The clinical details of the 25 patients who underwent pulmonary resection are summarized in Table 1 . All patients but 1 had solitary or resectable multiple lung tumors without uncontrolled hepatic disease. One patient (case 1) had multiple pulmonary metastases that were treated with systemic and bronchial arterial infusion chemotherapy for 26 months. The chemotherapy reduced his multiple tumors to 2 , but these 2 tumors persisted and began to enlarge again. However, this patient had become eligible for pulmonary resection after effective chemotherapy.

Eight patients (cases 2, 4, 5, 8, 14, 22, 23, and 24) had hepatic recurrence before the discovery of pulmonary metastases. All hepatic recurrences had been treated successfully by re-hepatectomy (cases 4, 14, 22, and 24), percutaneous ethanol injection therapy (cases 2, 4, and 8), transcatheter arterial chemoembolization (TACE) (cases 5 and 23), and/or percutaneous radiofrequency ablation therapy (case 22).

Wedge resection was performed in 21 patients, lobectomy in 2 patients, lobectomy plus wedge resection in 1 patient, and bilateral lobectomy in 1 patient. Six patients underwent a second pulmonary resection, and 1 patient underwent a third pulmonary resection. Altogether, the 25 patients underwent 32 pulmonary resections. There was 1 operative death as the result of pyothorax 19 days after a lobectomy, giving an operative mortality rate of $3.1 \%$. Ten patients died of HCC recurrence. One patient (case 9) died of sepsis 59 months after pulmonary resection, but he had no evidence of HCC involvement at death.

The median follow-up for patients after pulmonary resection was 37.3 months (range, 0.6-177.4 months). The median survival after pulmonary resection was 51.8 months. The actuarial overall 1-, 3-, and 5-year survivals after pulmonary resection were $80 \% \pm 8 \%, 61 \% \pm 10 \%$, and $36 \% \pm 13 \%$, respectively (Figure 1 ). Three patients (cases 1, 3, and 11) have survived more than 5 years. The first patient (case 1), who had the bilateral residual tumors after chemotherapy, underwent right upper and middle lobectomy and left lower lobectomy; he is alive with no recurrence at 177 months. Two tumors developed in the second patient's right lung after a DFI of 22 months (case 3); these were removed with a wedge resection. Subsequently, 2 masses developed in the left lung, necessitating a second partial lung resection at 10 months after the first. This patient is alive at 142 months with no evidence of recurrent disease. The third patient (case 11) underwent partial lung resection 3 times at 27, 33 , and 45 months after right hepatectomy. The first operation involved wedge resections for a tumor in the left lung and another in the right lung; the second was for a nodule in the right lung, and the third was for a tumor in the left lung. A new liver tumor appeared 2 years after the third pulmonary resection, but the liver disease was 
TABLE 1. Clinical details and surgical results of patients who underwent pulmonary resection for metastases from hepatocellular carcinoma

\begin{tabular}{|c|c|c|c|c|c|c|c|}
\hline $\begin{array}{l}\text { Patient } \\
\text { no. }\end{array}$ & Sex & Age (yr) & HBsAg/HCV-Ab & $\begin{array}{l}\text { Hepatic } \\
\text { treatment }\end{array}$ & $\begin{array}{l}\text { Disease-free } \\
\text { survival (mos) }\end{array}$ & $\begin{array}{c}\text { Pulmonary } \\
\text { tumor } \\
\text { number }\end{array}$ & $\begin{array}{c}\text { Pulmonary } \\
\text { tumor } \\
\text { location }\end{array}$ \\
\hline 1 & $\mathrm{M}$ & 32 & $+/$ n.a. & $\mathrm{Hx}$ & 7 & 2 & Bilateral \\
\hline 2 & $\mathrm{M}$ & 54 & -/n.a. & $\mathrm{Hx}, \mathrm{PEIT}$ & 16 & 1 & Unilateral \\
\hline 3 & $\mathrm{M}$ & 42 & $+1-$ & $\mathrm{Hx}$ & 22 & 2 & Unilateral \\
\hline 4 & $M$ & 43 & $+1-$ & $\mathrm{Hx}, \mathrm{Hx}, \mathrm{PEIT}$ & 1 & 4 & Bilateral \\
\hline 5 & $\mathrm{M}$ & 61 & $+1-$ & $\mathrm{Hx}, \mathrm{TACE}$ & 4 & 1 & Unilateral \\
\hline 6 & $\mathrm{M}$ & 54 & $+1-$ & $\mathrm{Hx}$ & 21 & 2 & Unilateral \\
\hline 7 & $\mathrm{M}$ & 37 & $+1-$ & $\mathrm{Hx}$ & 2 & 3 & Bilateral \\
\hline 8 & $\mathrm{M}$ & 68 & $-1-$ & Hx, PEIT & 22 & 3 & Unilateral \\
\hline 9 & $\mathrm{M}$ & 69 & $+1-$ & $\mathrm{Hx}$ & 26 & 5 & Unilateral \\
\hline 10 & $\mathrm{M}$ & 64 & $-1+$ & $\mathrm{Hx}$ & 16 & 6 & Bilateral \\
\hline 11 & $\mathrm{M}$ & 61 & $-/+$ & $H x$ & 26 & 2 & Bilateral \\
\hline 12 & $\mathrm{M}$ & 71 & $-1+$ & $\mathrm{Hx}$ & 33 & 1 & Unilateral \\
\hline 13 & $\mathrm{M}$ & 61 & $-1-$ & $H x$ & 10 & 1 & Unilateral \\
\hline 14 & $\mathrm{M}$ & 68 & $-1-$ & $H x, H x$ & 23 & 1 & Unilateral \\
\hline 15 & $\mathrm{M}$ & 46 & $+/+$ & $\mathrm{Hx}$ & 4 & 1 & Unilateral \\
\hline 16 & $\mathrm{M}$ & 74 & $-1-$ & $\mathrm{Hx}$ & 13 & 4 & Unilateral \\
\hline 17 & $\mathrm{M}$ & 49 & $-1-$ & $\mathrm{Hx}$ & 4 & 1 & Unilateral \\
\hline 18 & $\mathrm{M}$ & 50 & $+/-$ & $\mathrm{Hx}$ & 6 & 14 & Bilateral \\
\hline 19 & $\mathrm{~F}$ & 75 & $+1-$ & $\mathrm{Hx}$ & 34 & 1 & Unilateral \\
\hline 20 & $\mathrm{M}$ & 75 & $-1-$ & $\mathrm{Hx}$ & 29 & 3 & Bilateral \\
\hline 21 & $\mathrm{M}$ & 60 & $+/-$ & $\mathrm{Hx}$ & 6 & 4 & Bilateral \\
\hline 22 & $\mathrm{M}$ & 40 & $+/-$ & $\mathrm{Hx}, \mathrm{Hx}, \mathrm{RFA}$ & 7 & 1 & Unilateral \\
\hline 23 & $\mathrm{M}$ & 73 & $+/-$ & Hx, TACE & 37 & 1 & Unilateral \\
\hline 24 & $\mathrm{M}$ & 53 & $+/-$ & $H x, H x$ & 26 & 1 & Unilateral \\
\hline 25 & $\mathrm{~F}$ & 51 & $-1-$ & $H x$ & 13 & 2 & Unilateral \\
\hline
\end{tabular}

$H x$, hepatic resection; n.a., not available; $P E I T$, percutaneous ethanol injection therapy; $R F A$, radiofrequency ablation therapy; TACE, transcatheter arterial chemoembolization. *Recurrence organs at the follow-up end-point or to death, $\dagger$ Resected, $\bigcirc$; Recurrence disease was resected or well-controlled, Recurrence disease was uncontrolled or disseminated.

well controlled by TACE. He is alive at 68 months after the first pulmonary resection and remains disease-free at 25 months after TACE.

In the 24 patients who survived the immediate postoperative period, neither tumor number (solitary or multiple) nor tumor distribution (unilateral or bilateral lung) had a significant effect on survival (Table 2). The mean DFI was 16.3 months (range, 1-37 months). Ten patients had a DFI of 1 to 11 months, and 14 patients had a DFI of 12 months or more. When cancer-specific survival was analyzed according to length of DFI, the mean survival was 30.6 months for patients who were disease-free for less than 12 months versus 35.4 months for those who remained disease-free for 12 months or more $(P=.117)$ (Figure 2, $A)$.

Nineteen patients had serum AFP levels of less than 500 $\mathrm{ng} / \mathrm{mL}$; mean survival among these patients was 39.2 months. In the 5 patients with AFP levels of $500 \mathrm{ng} / \mathrm{mL}$ or more, mean survival was 15.9 months $(P=.225)$ (Figure 2, $B$ ).

Patients were then divided into 2 groups according to DFI and AFP levels. Group I patients (low-risk group, $\mathrm{n}=$

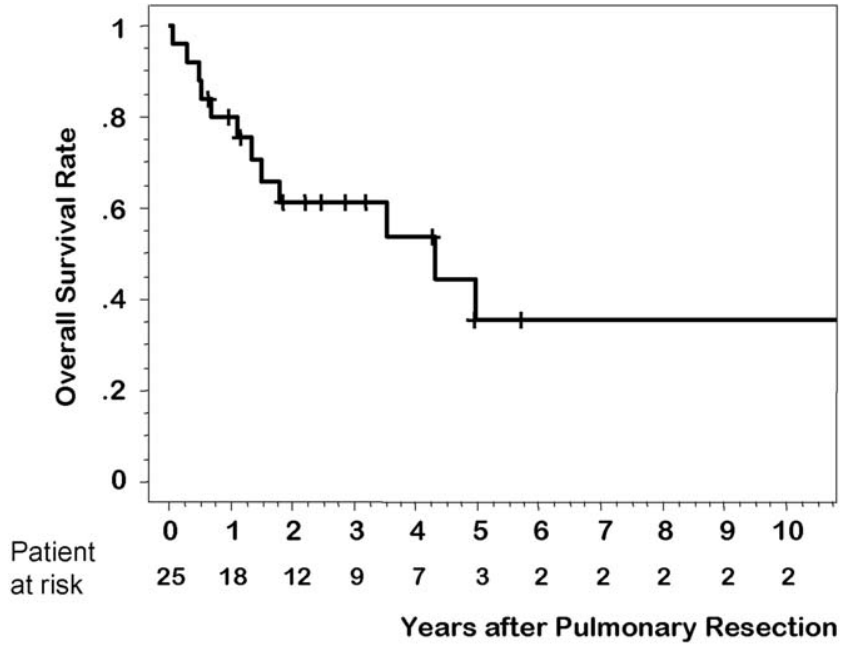

Figure 1. Overall survival in patients who underwent curative pulmonary metastasectomy from hepatocellular carcinoma $(n=25)$. 


\begin{tabular}{|c|c|c|c|c|c|c|}
\hline \multirow{2}{*}{$\begin{array}{l}\text { Serum AFP } \\
\text { level (ng/ } \\
\mathrm{mL})\end{array}$} & \multirow{2}{*}{$\begin{array}{l}\text { Repulmonary } \\
\text { resection } \\
\text { (times) }\end{array}$} & \multirow{2}{*}{$\begin{array}{c}\text { Survival } \\
\text { (mos) }\end{array}$} & \multirow[b]{2}{*}{ Outcome } & \multicolumn{3}{|c|}{ Recurrence site after pulmonary resection* } \\
\hline & & & & Liver & Lung & Others \\
\hline 3.5 & & 177 & Alive & & & \\
\hline 1433.7 & & 19 days & Dead, pyothorax & & & \\
\hline 432 & 1 & 142 & Alive & & $\bigcirc$ & \\
\hline 6.2 & & 51 & Dead & 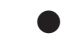 & $\bullet$ & \\
\hline 484 & & 6 & Dead & 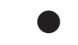 & & \\
\hline 599.7 & & 21 & Dead & & & Brain \\
\hline 12.6 & & 3 & Dead & 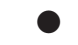 & & Adrenal gland \\
\hline 17.6 & & 16 & Dead & 0 & & \\
\hline 366 & 1 & 59 & Dead, free from HCC & & $\bigcirc$ & \\
\hline 6.1 & 1 & 42 & Dead & 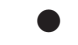 & $\bigcirc$ & \\
\hline 169 & 2 & 68 & Alive & & $\bigcirc, \bigcirc$ & \\
\hline 6.9 & & 59 & Alive & $\bigcirc$ & & Adrenal glandt, Bone \\
\hline 2260 & & 6 & Dead & & & Brain \\
\hline 34.5 & 1 & 51 & Alive & $\bigcirc$ & $\bigcirc$ & \\
\hline 484 & & 17 & Dead & & ? & Mediastinal lymph nodes \\
\hline 1.3 & & 34 & Alive & ○ & O & \\
\hline 5.8 & & 38 & Alive & & & Abdominal peritoneum \\
\hline 1181 & 1 & 29 & Alive & ○ & $0, \bigcirc$ & Mediastinal lymph nodes, Bone \\
\hline 97 & & 26 & Alive & & & \\
\hline 2341 & & 8 & Dead & & & $\begin{array}{l}\text { Mediastinal lymph nodes, } \\
\text { Carcinomatosa pleulitis }\end{array}$ \\
\hline 663 & & 22 & Alive & & 0 & \\
\hline 30.1 & & 13 & Dead & & ○ & Mediastinal lymph nodes, Brain \\
\hline 2.9 & & 14 & Alive & & & \\
\hline 1.6 & & 11 & Alive & & & \\
\hline 3 & & 7 & Alive & & & \\
\hline
\end{tabular}

12) had DFIs of 12 months or more and AFP levels less than $500 \mathrm{ng} / \mathrm{mL}$. Group II patients (high-risk group, $\mathrm{n}=12$ ) had DFIs less than 12 months or AFP levels of $500 \mathrm{ng} / \mathrm{mL}$ or more. Overall survivals at 3 and 5 years were $89 \% \pm 11 \%$ and $74 \% \pm 16 \%$, respectively, for group I patients and $42 \%$ $\pm 14 \%$ and $21 \% \pm 16 \%$, respectively, for group II patients

TABLE 2. Kaplan-Meier analysis of cancer-specific survival ( $P$ Value, Log Rank)

\begin{tabular}{|c|c|c|c|c|c|}
\hline Factor & $\mathbf{n}$ & 1-year survival, \% & 3-year survival, \% & 5-year survival, \% & $P$ Value \\
\hline \multicolumn{6}{|l|}{ Tumor number } \\
\hline Single & 10 & 80 & 55 & - & 0.683 \\
\hline Multiple & 14 & 85 & 70 & 46 & \\
\hline \multicolumn{6}{|l|}{ Tumor location } \\
\hline Unilateral & 16 & 88 & 56 & 56 & 0.918 \\
\hline Bilateral & 8 & 75 & 75 & 38 & \\
\hline \multicolumn{6}{|c|}{ Disease-free survival } \\
\hline Under 12 mos & 10 & 70 & 50 & 25 & 0.117 \\
\hline Over 12 mos & 14 & 92 & 74 & 62 & \\
\hline \multicolumn{6}{|l|}{$\begin{array}{l}\text { Serum AFP level } \\
(\mathrm{ng} / \mathrm{ml})\end{array}$} \\
\hline$<500$ & 19 & 90 & 71 & 52 & 0.225 \\
\hline$\geqq 500$ & 5 & 60 & - & - & \\
\hline
\end{tabular}



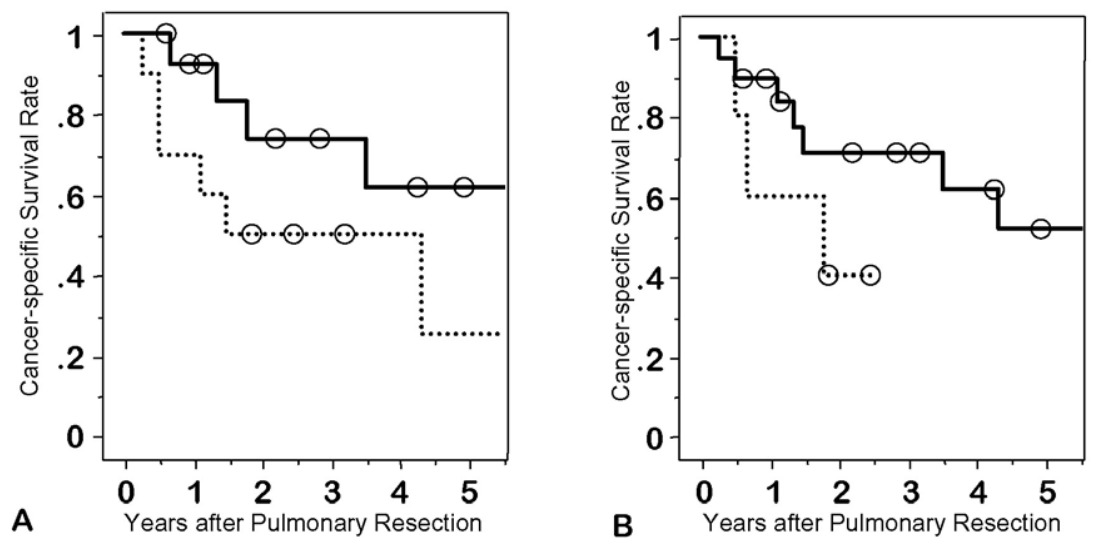

Figure 2. Cancer-specific survival in patients with pulmonary metastasectomy. A, According to the DFI: $\geq 12$ months $(n=14)$ (solid line), $<12$ months ( $=10)$ (dotted line). $B$, According to the serum AFP level at prepulmonary resection: $<500 \mathrm{ng} / \mathrm{mL}(\mathrm{n}=19)$ (solid line); $\geq 500 \mathrm{ng} / \mathrm{mL}(\mathrm{n}=5)$ (dotted line).

$(P=.015)$ (Figure 3$)$. The number of patients who had recurrence after pulmonary metastasectomy is shown in Table 3. The incidences of intrahepatic recurrence and pulmonary re-recurrence did not differ between the low- and high-risk groups. Five of 6 low-risk patients who had pulmonary re-recurrence required further resection. In all 5 high-risk patients with pulmonary re-recurrence, however, pulmonary involvement was disseminated. The incidence of metastases to other organs was significantly higher in the high-risk group than in the low-risk group $(P=.003$, chi-square test).

\section{Discussion}

Advances in surgical techniques and perioperative management have resulted in better outcomes and lower operative mortality rates in patients with HCC in recent years. ${ }^{4}$ Still, the recurrence rate after curative resection of HCC is high, with distant metastasis most frequently found in the lung. ${ }^{4}$ In our experience, only a few cases were suitable for surgical resection.

The few English-language reports on pulmonary resection of metastases from HCC are summarized in Table 4. Lam and colleagues ${ }^{8}$ described 9 cases of pulmonary resection. Their 5-year survival of $67 \%$ is better than our rate of $36 \%$, but their patients had solitary metastases and long DFIs. They did not perform resections on patients with multiple lung metastases. In a series reported by Chen and colleagues, ${ }^{10} 5$ of 6 patients had multiple pulmonary metastases.

Rusch $^{11}$ asserted in a review article that the objective of resection of pulmonary metastases is to remove all gross tumor while preserving as much normal pulmonary parenchyma as possible. We considered patients to be candidates for curative resection as long as their respiratory function could be preserved. In fact, we found no significant difference in survival between patients with solitary tumors and patients with multiple tumors. Three patients in our series are still alive more than 5 years after pulmonary resection.
Each had 2 pulmonary metastatic tumors. Thus, our experience suggests that curative resection might allow a good prognosis even in patients with multiple pulmonary metastases.

In our series, DFI was an important prognostic factor. ${ }^{12,13}$ Some authors have reported that a DFI more than 36 months is a good prognostic factor in colorectal cancer ${ }^{14}$ or breast cancer. ${ }^{15}$ Those authors calculated the DFI as starting at the surgical resection of the primary tumor, whereas we considered it to begin at the last curative treatment for intrahepatic disease. We defined the DFI in this way because patients were often treated for intrahepatic HCC recurrence several times before distant metastases appeared.

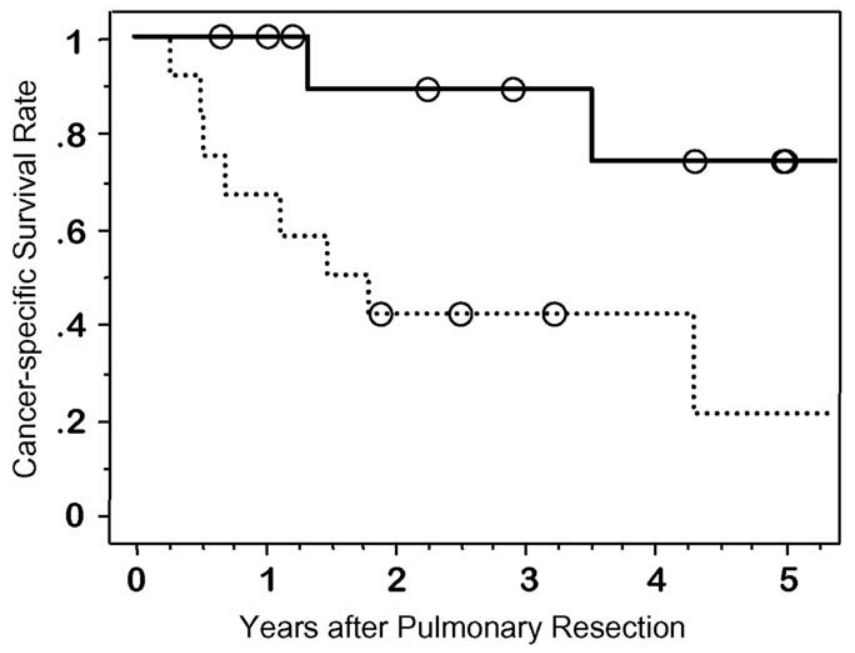

Figure 3. Cancer-specific survival related to the DFI and serum AFP level at pre-pulmonary resection. Low-risk group (solid line): DFI $\geq 12$ months and AFP $<500 \mathrm{ng} / \mathrm{mL}$ ( $\mathrm{n}=12$ ). High-risk group (dotted line): DFI $<12$ months and AFP $\geq 500 \mathrm{ng} / \mathrm{mL}$ ( $=12$ ); log-rank test: $P=.015$ 
TABLE 3. Comparison of recurrence cases after pulmonary resection among low and high risk groups ( $P$ Value, Chi square test)

\begin{tabular}{lccc}
\hline Recurrence site & $\begin{array}{c}\text { Low risk group } \\
(\mathbf{n}=\mathbf{1 2})\end{array}$ & $\begin{array}{c}\text { High risk group } \\
(\mathbf{n}=\mathbf{1 2})\end{array}$ & P Value \\
\hline Liver & & & \\
Absent & 6 & 8 & 0.408 \\
Present & 6 & 4 & \\
Lung & & & \\
Absent & 6 & 7 & 0.682 \\
$\quad$ Present & 6 & 5 & \\
Others & & & \\
Absent & 11 & 4 & $\mathbf{0 . 0 0 3}$ \\
Present & 1 & 8 & \\
\hline
\end{tabular}

Bold typeface indicates statistically significant.
In an analysis of patients with pulmonary metastases from colorectal cancer, carcinoembryonic antigen level was a significant prognostic factor; patients were divided into 2 groups according to whether their carcinoembryonic antigen levels were normal or elevated $(>5 \mathrm{ng} /$ $\mathrm{mL}) .{ }^{14}$ In a study of patients with HCC with primary lesions, the Cancer of the Liver Italian Program investigators ${ }^{16}$ developed a scoring system that included as 1 of its components an AFP level greater than or less than 400 $\mathrm{ng} / \mathrm{dL}$. Hanazaki and colleagues ${ }^{17}$ reported that serum AFP level was a significant prognostic factor after hepatic resection of hepatitis $C$ virus-related primary HCC. In their study, the cutoff value of AFP was $1000 \mathrm{ng} / \mathrm{mL}$. As in other studies, serum AFP level before pulmonary metastasectomy was a prognostic factor in our study. We found $500 \mathrm{ng} / \mathrm{mL}$ to be the cutoff value that in combination with DFI could separate high- and low-risk groups

TABLE 4. Summary of studies for pulmonary metastasectomy of hepatocellular carcinoma

\begin{tabular}{|c|c|c|c|c|c|c|c|}
\hline $\begin{array}{l}\text { Study and } \\
\text { location }\end{array}$ & Patients number & & $\begin{array}{l}\text { Criteria for pulmonary } \\
\text { resection }\end{array}$ & Tumor number St: $\mathbf{M t}$ & $\begin{array}{l}\text { Disease-free } \\
\text { interval, } \\
\text { month, mean } \\
\text { (range) }\end{array}$ & $\begin{array}{l}\text { Median survival } \\
\text { after pulmonary } \\
\text { resection } \\
\text { (longest } \\
\text { survivor) }\end{array}$ & $\begin{array}{l}\text { 5-year survival } \\
\text { rate }\end{array}$ \\
\hline $\begin{array}{l}\text { Lam et al. } \\
\quad 1998\end{array}$ & 9 post-Hx & 1. & $\begin{array}{l}\text { Solitary pulmonary } \\
\text { tumor }\end{array}$ & 9:0 & $21.8(10-51)$ & $42 \mathrm{mos}$ & $67 \%$ \\
\hline Hong Kong & & 2. & $\begin{array}{l}\text { Without concurrent } \\
\text { intrahepatic } \\
\text { recurrence }\end{array}$ & & & $\begin{array}{l}\text { (127 mos } \\
\text { alive) }\end{array}$ & \\
\hline $\begin{array}{l}\text { Gwak et al. }^{9} \\
2004\end{array}$ & 2 post-Hx and & 1. & $\begin{array}{l}\text { Without concurrent } \\
\text { intrahepatic } \\
\text { recurrence }\end{array}$ & $3: 1$ & $10.3(0-35)$ & Not described & Not described \\
\hline $\begin{array}{l}\text { Republic of } \\
\text { Korea }\end{array}$ & 2 post-TACE & 2. & $\begin{array}{l}\text { The metastatic lesions } \\
\text { appeared to be } \\
\text { amenable to complete } \\
\text { resection } \\
\text { No evidence of } \\
\text { metastatic disease at } \\
\text { another site }\end{array}$ & & & (72 mos alive) & \\
\hline $\begin{array}{l}\text { Chen et al. } \\
2004 \\
\text { Taiwan }\end{array}$ & 6 post-Hx & \multicolumn{2}{|c|}{$\begin{array}{l}\text { Without concurrent } \\
\text { intrahepatic recurrence }\end{array}$} & $1: 5$ & $27.8(10-75)$ & $\begin{array}{l}47 \text { mos (mean } \\
\text { survival) } \\
\text { (94 mos } \\
\text { alive) }\end{array}$ & Not described \\
\hline Our series & 25 post-Hx & 1. & $\begin{array}{l}\text { No evidence of } \\
\text { uncontrollable } \\
\text { intrahepatic disease } \\
\text { No evidence of } \\
\text { metastatic disease at } \\
\text { another site } \\
\text { Complete resection } \\
\text { could be performed } \\
\text { regardless of the } \\
\text { number or the lesions }\end{array}$ & $10: 14$ & $16.3(1-37)$ & $\begin{array}{l}\text { (177 mos } \\
\text { alive) }\end{array}$ & $36 \%$ \\
\hline
\end{tabular}

$H x$, hepatic resection; TACE, transcatheter arterial chemoembolization; St, solitary; Mt, multiple. 
with statistical significance. In living-donor liver transplantation for adult patients with HCC, pretransplant serum AFP level is significantly associated with patient survival on univariate analysis and independent risk factors by multivariate analysis. ${ }^{18}$ Poor tumor cell differentiation is a poor prognostic factor, and serum AFP level is related to HCC cell differentiation. ${ }^{19}$ A high AFP level is a poor prognostic factor not only in the metastatic stage but also in several clinical features.

Although neither DFI nor AFP level alone was a statistically significant prognostic factor, survival in groups divided according to a combination of these parameters was significantly different. Patients with short DFIs or high AFP levels had a high incidence of disseminated pulmonary reappearance and distant metastases. In these high-risk patients, even when it seems that curative resection of pulmonary metastases is possible, it is likely that occult metastases are present and their disease is widespread.

\section{Conclusion}

Our investigation showed that a DFI of more than 1 year and a serum AFP level less than $500 \mathrm{ng} / \mathrm{mL}$ together predict a better outcome after pulmonary metastasectomy of HCC, with 3- and 5-year survivals of $89 \%$ and $74 \%$, respectively. Aggressive surgical management of resectable pulmonary metastases from HCC is justified in selected patients.

The authors thank the staff of the First Department of Surgery, Hokkaido University Medical Hospital for their clinical assistance, and Ms Nancy Ehrlich Lapid for editorial assistance.

\section{References}

1. Ikai I, Itai Y, Okita K, Omata M, Kojiro M, Kobayashi K, et al. Report of the 15th follow-up survey of primary liver cancer. Hepatol Res. 2004;28:21-9.

2. El-Serag HB. Hepatocellular carcinoma: recent trends in the United States. Gastroenterology. 2004;127:S27-S34.

3. Jaeck D, Bachellier P, Oussoultzoglou E, Weber JC, Wolf P. Surgical resection of hepatocellular carcinoma. Post-operative outcome and longterm results in Europe: an overview. Liver Transpl. 2004;10:S58-S63.

4. Ikai I, Arii S, Kojiro M, Ichida T, Makuuchi M, Matsuyama Y, et al. Reevaluation of prognostic factors for survival after liver resection in patients with hepatocellular carcinoma in a Japanese nationwide survey. Cancer. 2004;101:796-802.

5. Sasaki Y, Imaoka S, Shibata T, Wada H, Nagano H, Ishikawa O, et al. Successful surgical management of pulmonary and adrenal metastases from hepatocellular carcinoma. Eur J Surg Oncol. 1991;17:84-90.

6. Aramaki M, Kawano K, Sasaki A, Matsumoto T, Kai S, Iwashita Y, et al Prolonged survival after repeat resection of pulmonary metastasis from hepatocellular carcinoma. J Hepatobiliary Pancreat Surg. 2002;9:386-8.

7. O'Suilleabhain CB, Poon RT, Lau CW, Fan ST. Repeated resections of extrahepatic metastases after hepatic resection: an aggressive approach to hepatocellular carcinoma. Hepatogastroenterology. 2004; 51:825-9.

8. Lam CM, Lo CM, Yuen WK, Liu CL, Fan ST. Prolonged survival in selected patients following surgical resection for pulmonary metastasis from hepatocellular carcinoma. Br J Surg. 1998;85:1198-200.

9. Gwak GY, Jung JO, Sung SW, Lee HS. Long-term survival after pulmonary metastasectomy of hepatocellular carcinoma; treatment outcome or natural history? Hepatogastroenterology. 2004;51:1428-33.

10. Chen YJ, Hsu HS, Hsieh CC, Wu YC, Wang LS, Hsu WH, et al. Pulmonary metastasectomy for hepatocellular carcinoma. J Chin Med Assoc. 2004:67:621-4.

11. Rusch VW. Pulmonary metastasectomy. Current indications. Chest. 1995; 107:322S-31S

12. Roberts DG, Leporte V, Cardillo G, Dernevik I, Berggen H, Belboul A, et al. Long-term follow-up of operative treatment for pulmonary metastases. Eur J Cardiothorac Surg. 1989;3:292-6.

13. Putnam JB Jr, Roth JA, Wesley MN, Johnston MR, Rosenberg SA. Analysis of prognostic factors in patients undergoing resection of pulmonary metastases from soft tissue sarcomas. J Thorac Cardiovasc Surg. 1984;87:260-8.

14. Rena O, Casadio C, Viano F, Cristofori R, Ruffini E, Filosso PL, et al Pulmonary resection for metastases from colorectal cancer: factors influencing prognosis. Twenty-year experience. Eur J Cardiothorac Surg. 2002;21:906-12.

15. Friedel G, Pastorino U, Ginsberg RJ, Goldstraw P, Johnston M, Pass $\mathrm{H}$, et al. Results of lung metastasectomy from breast cancer: prognostic criteria on the basis of 467 cases of the international registry of lung metastases. Eur J Cardiothorac Surg. 2002;22:335-44.

16. A new prognostic system for hepatocellular carcinoma: a retrospective study of 435 patients: The Cancer of the Liver Italian Program (CLIP) investigators. Hepatology. 1998;28:751-5.

17. Hanazaki K, Kajikawa S, Koide N, Adachi W, Amano J. Prognostic factors after hepatic resection for hepatocellular carcinoma with hepatitis $\mathrm{C}$ viral infection: univariate and multivariate analysis. Am J Gastroenterol. 2001;96:1243-50.

18. Todo S, Furukawa H, Japanese Study Group on Organ Transplantation. Living donor liver transplantation for adult patients with hepatocellular carcinoma: experience in Japan. Ann Surg. 2004;240:451-9.

19. Imamura H, Matsuyama $Y$, Miyagawa $Y$, Ishida K, Shimada R, Miyagawa $S$, et al. Prognostic significance of anatomical resection and des-gamma-carboxy prothrombin in patients with hepatocellular carcinoma. Br J Surg. 1999;86:1032-8. 